\title{
An analysis of the tourism and wider economic impacts of price-reducing reforms in air transport services in Egypt
}

\begin{abstract}
The Egyptian air transport industry is subject to a range of restrictions and charges that reduce the country's air connectivity and competitiveness. This paper assesses links between air transport policies, tourism and wider economic benefits. It estimates the distortions imposed by Egypt's current, relatively closed air space on the price of air transport. It then examines the effects of their reduction by simulating the direct and indirect impacts of price-reducing reforms to air transport services. The results indicate that while the direct impacts of these reforms are negative for some agents, the economy-wide benefits outweigh the costs incurred by the reforming sector. It is argued that Egypt would benefit from pursuing reforms to the air transport industry.
\end{abstract}

\section{Keywords:}

Air transport and tourism; Air transport in Egypt; Computable general equilibrium; Wider economic benefits; Price-reducing reforms.

\section{Introduction}

Air transport has increasingly emerged as the preferred mode of transport for international tourism, with a 55\% share in 2016 compared with 38\% in 1980 (UNWTO, 2017). The forces driving the rapid growth of air transport and the role it has played in promoting tourism, trade and economic development are well-documented (Oxford Economic Forecasting, 2003; Dwyer and Forsyth, 2007; Graham, Papatheodorou and Forsyth, 2008; IATA, 2014). Changes to air transport policy, as well as air transport infrastructure constraints, have important implications for tourism planning, development and management (Abeyratne, 1993; Duval, 2013; Mayor and Tol, 2010; Seetaram, Song and Page, 2014; Debbage, 2002; Crouch, 1992; Forsyth, 2006; Njoya et al., 2018). Previous studies have established a clear bi-directional relationship between air transport and tourism. For example, it has been shown that aviation taxation is detrimental to the development of tourism (Ikiara and Nyangito, 2001; Mayor and Tol, 2010; Tol, 2007; Seetaram et al., 2014; Forsyth, Niemeier and Njoya, 2015), while the tourism infrastructure has contributed to the development of air traffic 
and low-cost carriers in Europe (Bieger and Wittmer, 2006). Using a computable general equilibrium (CGE) model, Forsyth et al. (2015) estimate the potential effects on tourism and the economy of an increase in Australia's Passenger Movement Charge rate in the inbound, outbound and domestic markets, concluding that although these markets would experience a contraction in outputs, the Australian economy would gain, with most of the total positive economic effects accruing to nontourism industries. The authors argue that tourism-related industries may gain or lose from an aviation tax, depending on the price elasticity of demand for inbound and outbound travel, substitution between domestic and outbound tourism, and the balance of inbound and outbound tourism.

Forsyth et al.'s (2015) study clearly illustrates that in evaluating the impact of air transport policy, it is essential to take a wider-economy approach by examining the effects on other sectors and the economy as a whole. CGE models have emerged in recent years as the most comprehensive tools to capture the economy-wide impacts of air transport policy and investments (Forsyth et al., 2015). Unlike partial equilibrium models of individual sectors, CGE models account for inter-industry and inter-institutional linkages and simulate the net benefits of a policy or project proposal.

Travel and tourism play a vital role in the Egyptian economy, generating employment and contributing to national income. The sector's total contribution (including indirect and induced impacts) was $8.5 \%$ to employment and $11.0 \%$ to GDP in 2017 (WTTC, 2018). According to IATA (2017), air transport contributes significantly to the Egyptian economy in terms of job creation, tax revenues, GDP and tourism development. In 2014, air transport and foreign tourists arriving by air accounted for $4.4 \%$ of the country's GDP. Recognising the benefits of air connectivity, in recent years Egypt has taken steps to improve air access to the country, including air transport liberalisation and infrastructure development (O'Connell and Warnock-Smith, 2012; Schlumberger and Weisskopf, 2012). Despite these developments, barriers to trade in the air transport sector remain relatively high. According to export.gov (n.d.), the bilateral aviation safety agreement (BASA) concluded between Egypt and the United States in 1964 remains restrictive, with limited agreement on cooperative marketing arrangements that provide for charter services. Private and foreign air carriers require approval from the national carrier, EgyptAir, to operate charter flights to and from Cairo. Using partial equilibrium techniques, previous studies have shown that air transport liberalisation in Egypt would result in lower fares (Omar and Sekkat, 2012), and full liberalisation would be likely to result in a substantial increase in tourist arrivals, jobs and GDP (WTTC, 2005). 
Unlike previous studies, this paper develops a comparative static CGE model of Egypt that can capture the economy-wide impact of Egyptian service sector reforms. This model is then used to simulate the impacts on tourism and the wider economy of price-reducing reforms to air transport services in Egypt. Reductions in the price of air transport may be brought about by air transport liberalisation, improvements to airport infrastructure, tax reductions or subsidies. For instance, Micco and Serebrisky (2004) show that improving airport infrastructure in the United States from the 25 th to 75 th percentiles reduces air transport costs by $15 \%$. A similar improvement in the quality of regulation reduces air transport costs by $14 \%$, and open skies agreements further reduce these costs by $8 \%$.

In the remainder of this paper, Section 2 provides an overview of aeropolitics in Egypt, Section 3 documents the data and methodology used to calibrate the model, Section 4 explains the design of the simulations, and Section 5 presents the findings and interprets the results of the study. Some conclusions are then drawn in Section 6.

\section{The regulatory environment of Egyptian air services}

The current dynamism of the Egyptian air services sector largely reflects economic reforms in this sector and in the wider economy since 1991, in the context of stabilisation and structural adjustment programmes (Schlumberger and Weisskopf, 2012; Tohamy, 1999). The most significant aspects of these reforms have been the removal of obstacles to new airlines based in Egypt operating domestic routes, and facilitation of foreign carriers' access to Cairo International Airport (CAl; Schlumberger and Weisskopf, 2012). At the African level, Egypt has signed the Yamoussoukro Decision and engages in the Single African Air Transport Market, two initiatives that seek to liberalise access to African air transport markets. However, it has not signed the agreement on liberalisation of air transport between Arab States, commonly known as the Damascus Agreement, which provides for unlimited third, fourth and fifth freedom rights between points in signatory states (ICAO, 2016).

Despite considerable efforts in recent years to liberalise and expand international trade in air transport in Egypt, some restrictions remain (Schlumberger and Weisskopf, 2012). The government retains its public monopoly at the main airports such as CAI, and Egypt Air still has a monopoly on domestic air transport, with minimal private-sector charter competition (Schlumberger and Weisskopf, 2012; OECD, 2014). Restrictions on capacity, frequency and routes are built into existing BASAs, and there are limitations and constraints on the operations of privately-owned Egyptian airlines and airline designations (ICAO, 2014). According to IATA (2018), industry costs have 
increased by $\$ 1.6$ billion in the Middle East and North Africa region since 2016 . This has impacted on the industry's profitability, with airlines in this region forecast to earn about $\$ 5.89$ per passenger in 2018, well below the global average of $\$ 7.76$.

The impacts of recent and potential aviation reforms have been studied using both partial and general equilibrium approaches. Omar and Sekkat (2012) examine the link between air service liberalisation and the performance of the Egyptian airline market. They find that liberalisation has had two conflicting effects on EgyptAir passengers: a direct negative impact on the home carrier, which has experienced a decrease in the number of passengers as they have switched to other carriers, and an indirect positive effect due to fare reductions. Moreover, the total number of passengers to and from Egypt has increased in the wake of liberalisation, resulting from competition and low fares (Omar and Sekkat, 2012). This finding is in line with those of previous studies, which reveal that liberalisation may adversely affect home carriers (Kincaid and Tretheway, 2016). IATA (2014) shows that liberalisation between Egypt and 11 large African countries would lead to a significant increase in passengers, employment, GDP and consumer benefits. Thus, with intraAfrican liberalisation, the Egyptian aviation industry would experience a 318,000 increase in passengers, with national GDP rising by US\$114 million, consumer benefits by US\$68 million and jobs by 11,300 . Moreover, average fares would decrease by $32 \%$. Similarly, Cristea, Hillberry and Mattoo (2015) demonstrate that deepening the plurilateral agreement between Arab states would lead to a $30 \%$ increase in intraregional passenger traffic.

Using an economic impact analysis (EIA) approach, WTTC (2005) estimates the impact of the Egyptian government's adoption of an open skies regime on the Egyptian travel and tourism industry and the national economy. The study shows that, compared with 2006, full liberalisation would lead to 2.5 million more tourist arrivals by 2011, with an additional 225,000 jobs and an extra US\$1.6 billion in GDP from travel and tourism. A strength of the study is the wider-economy approach to the reform, taking into account both direct and indirect impacts of liberalisation. Despite this advantage over partial equilibrium models, EIA models rely on a number of assumptions, such as fixed prices, fixed-coefficient technologies and absence of resource constraints. Therefore, they cannot be used explicitly to examine the potential costs and benefits of air transport reforms. CGE models are capable of overcoming the major limiting assumptions of EIA models and are theoretically more satisfactory, offering greater flexibility in evaluating the wider economic impact of sectoral policy reforms (Forsyth et al., 2015; Dwyer et al., 2004). Although the use of CGE models is a well-established approach to assessing Egyptian policy issues, no CGE analysis 
has previously been carried out on air transport in Egypt. Lofgren (1994) and Thissen (1998) review early CGE models applied to Egypt. Previous applications to the Egyptian economy have been concerned with trade liberalisation and tax reform (Zaki, 2009, 2010, 2013; Konan and Kim, 2004; Hendy and Zaki, 2010; Evans et al., 2006; Maskus and Konan, 1997), the effects of subsidies (Lofgren, 1995; Cockburn et al., 2018, foreign trade (Nugent, 1988) and transportation (Elshahawany, Haddad and Lahr, 2017). Elshahawany et al. (2017) use a spatial CGE model to estimate the economic impacts of changes to transportation costs due specifically to changes in accessibility arising from new transportation projects. They show that infrastructure projects would have positive long-term effects on Egypt's economy, in terms of GDP growth, efficiency gains and welfare gains (measured by equivalent variation).

\section{Data and methodology}

Very little quantitative analysis has been undertaken of the wider economic impact of air service liberalisation in Egypt and elsewhere, despite recent improvements to CGE modelling of service liberalisation (see Balistreri, Rutherford and Tarr, 2008; Konan and Maskus, 2006; Konan and Van Assche, 2007; Abayasiri-Silva and Horridge, 1998; Harris, 1984; Elbehri and Hertel, 2004; Roson, 2006). Building on the above studies, an air transport-focused CGE model was developed to study the effects on the Egyptian economy of price-reducing reforms to air transport services. This model is based on Decaluwé et al.'s (2010) PEP-1-1 standard model, and is formulated as a system of nonlinear equations solved simultaneously for the set of prices and allocations of goods and factors that clear all markets. Its main features are profit maximisation by producers, utility maximisation by households, and perfect and imperfect markets. The set of equations includes equations specifying (1) the behaviour of the producer and the representative household and the technological and institutional constraints they face; and (2) price, income, savings and expenditure of all agents, international trade, the model's pricing system, and equilibrium conditions. ${ }^{1}$

Production and factor demand functions: Production of goods and services is assumed to be competitive, and technology is specified by constant returns to scale, while the service sector, including air transport, is characterised by oligopolistic competition, product variety, increasing returns to scale due to fixed costs, and cross-border investment. Goods and services are produced according to a nested Leontief-constant elasticity of substitution (CES) technology, with CES

\footnotetext{
${ }^{1}$ For reasons of space, we only explain the modelling of the air transport sector, since the specification of air transport services and the modelling of imperfection are where this model diverges from the standard model.
} 
functions specified to represent substitution of capital and labour, which are the primary factors of production in each sector.

Product demand: Final demand comprises demand from the representative household, investment, inventory, the government and the rest of the world. The household is assumed to choose to consume different goods according to a linear expenditure system (LES) formulation, with fixed minimum consumption bundles and fixed shares of each commodity. Investment in volume is exogenous to the model, illustrating a situation in which policy makers have specific investment volume objectives, such as expenditure on equipment. The model is driven by investment, i.e. investment-driven savings, with the value of savings adjusting for changes in economy-wide investments to fulfil the savings-investment clearing condition. The value of government expenditure is equal to the sum of government demand for commodities, defined as constant shares of total fixed real government expenditure, plus transfer payments to households.

The model includes 53 goods and services, which are divided into two categories that define their treatment in the model formulation. These include 33 perfectly competitive sectors in which goods and services are produced under constant return to scale, with prices equal to marginal costs with zero profits, and 20 imperfect competitive sectors where goods and services are produced under increasing return to scale and imperfect competition. Competitive sectors include agriculture and light manufacturing, in which products are differentiated by country of origin. In other words, the Armington (1969) assumption is employed (Equation 1).

Thus, for each category of commodities $i$, the demand for composite commodity $Q_{i}$ is defined by the CES function $\sigma_{i}$ of domestic commodity $D_{i}$ and imported commodity $M_{i}$.

$$
Q_{i}=A_{i}\left[\mu_{i} D^{\frac{\sigma_{i}-1}{\sigma_{i}}}+\left(1-\mu_{i}\right) M^{\frac{\sigma_{i}-1}{\sigma_{i}}}\right]^{\frac{\sigma_{i}}{\sigma_{i}-1}}
$$

where $A_{i}$ and $\mu_{i}$ are efficiency and share parameters, respectively, and $\sigma_{i}$ is a substitution parameter. Similarly, the aggregate domestic output is allocated between domestic and export markets under the assumption that suppliers maximise sales revenues for any given aggregate output level, subject to imperfect transformability between exports and domestic sales, expressed by a constant elasticity of transformation (CET) function. Differentiation between exports and domestically consumed goods may arise from differences in quality.

Under imperfect competition, goods are differentiated at the firm level, along the lines of Dixit and Stiglitz (1977). Modelling imperfect competition involves specifying how rents are generated and distributed (Davies and Van Seventer, 2006). Konan and Van Assche (2007) show that restraints 
on trade in services involve both restrictions on cross-border supply and foreign ownership through foreign direct investment. The former is modelled as tariff-equivalent price wedges, while the latter comprises both monopoly-rent distortions (arising from imperfect competition between domestic producers) and inefficiency costs (arising from failure of domestic service providers to adopt leastcost practices). It should be noted that although the tariff equivalent is the most widely-used approach to modelling restrictions on cross-border supply, other approaches to handling non-tariff barriers are available. Andriamananjara, Ferrantino and Tsigas (2003) show that it is possible to view non-tariff barriers as regulatory measures that create efficiency losses but generate no rents. Removing such barriers would enhance import productivity (Davies and Van Seventer, 2006).

Following Konan and Van Assche (2007) and Davies and Van Seventer (2006), we impose an ad valorem tariff equivalent on imports of air transport services in Egypt, in precisely the same way that one would introduce an explicit tariff. This tariff generates an income, which we allocate to the government (Equation 2). Equation 2 defines the price of imported product $m$ (including all taxes and tariffs).

$$
P M_{m}=\left[\left(1+n t m_{m}+t t i m_{m}\right) e P W M_{m}+\sum_{c} P C_{c}+t m r g_{c, m}\right]\left(1+t t i c_{m}\right) \quad \text { Eq. } 2
$$

where $P M_{m}$ is the import price, $n t m_{m}$ is the non-tariff barrier, $t$ tim $m_{m}$ is the rate of taxes and duties on imports of commodity $m, e$ is the exchange rate (price of foreign currency in local currency), $P W M_{m}$ is the world price of imported product $m$ (expressed in foreign currency), $P C_{c}$ is the purchase price of composite commodity $c$ (including all taxes and margins), $\operatorname{tmrg}_{c, m}$ is the rate of margin $c$ applied to commodity $m$, and $t t i c_{m}$ is the tax rate on commodity $m$.

Adopting the same approach as Konan and Van Assche (2007) and Davies and Van Seventer (2006), we model the rents by introducing an exogenous mark-up on the price of air transport. Imperfect competition is therefore introduced as a mark-up on the price received for domestic sales, $P D c$ (Equation 3). This interposes a wedge between $P D c$ and $P C c$, the demanders' price, on top of any existing trade and transport margins. Equation 3 represents the price of local product $c$ sold on the domestic market (including all taxes and margins).

$$
P D_{c}=\left(P D M_{c}+\sum_{c a} P C_{a c} \operatorname{tmrg}_{c a}\right)\left(1+t t i c_{c}\right)
$$

The price of the commodity produced in different sectors is essentially cost-driven. In this formulation, we can see that the mark-up drives a wedge between the price suppliers receive and the price demanders pay for sales in the domestic market (Equation 4).

$$
P D M_{c}=M K P_{c} P L_{c}
$$


where $P D M_{c}$ is the mark-up price, $M K P_{c}$ is the mark-up, and $P L_{c}$ is the domestic supply price.

Following Hosoe, Gasawa and Hashimoto (2010), we assume that rents accrue entirely as income from capital in the activity, meaning that it is distributed in the same way as 'normal' profits.

We model the efficiency component that would arise from domestic service providers' adoption of least-cost practices as a decline in multifactor productivity on air service activities. Efficiency is captured using an efficiency parameter (Equation 5) that defines value added, which is generated through the combination of composite capital and composite labour, following a CES specification.

$$
V A_{a}=B_{a}^{v a}\left(1+\operatorname{prodadj}_{a}\right)\left[\delta_{a}^{v a} L D C_{a}^{-\rho_{a}^{v a}}+\left(1+\delta_{a}^{v a}\right) K D C_{a}^{-\rho_{a}^{v a}}\right]^{-\left(1 / \rho_{a}^{v a}\right)} \quad \text { Eq. } 5
$$

where $V A_{a}$ is the value-added by activity $a, B_{a}^{v a}$ is a scale parameter (CES - value added), prodadj $j_{a}$ is an efficiency parameter (multifactor productivity), $\delta_{a}^{v a}$ is a share parameter (CES - value added), $L D C_{a}$ is activity $a^{\prime} s$ demand for composite labour, $K D C_{a}$ is activity $a^{\prime}$ s demand for composite capital, and $\rho_{a}^{v a}$ is an elasticity parameter (CES - value-added).

Intermediate consumption is modelled in a Leontief fashion as follows:

$$
I R M_{c, a}=i c a_{c, a} * I R D_{a}
$$

where $I R M_{c, a}$ is the total intermediate consumption of activity $a, I R D_{a}$ is the intermediate consumption of commodity $c$ by activity $a$, and $i c a_{c, a}$ is the input-output coefficient.

Income, savings prices and equilibrium condition: A set of equations describes the income and savings of various institutions, and the trade balance, prices and market clearing for composite commodities and primary factors. Equation 7 defines total household income, including rents from mark-ups and non-tariff measures. We create a fictitious agent who earns the monopoly rents, assuming that the rents are first captured by the firms and then transferred to the agent (Hosoe et al., 2010).

$$
\begin{aligned}
& Y H=Y H L+Y H T R+Y F K+\sum_{c} m_{k p s h r_{i n s d n g}}\left(P D M_{c}-P L_{c}\right) Q_{c}+ \\
& \sum_{c} n t m s h r_{\text {insdng }} n t m_{m} e P W M_{m} I M_{m}
\end{aligned}
$$

where $Y H$ is the total household income, $Y H L$ is the household's labour income, YHTR is the household's transfer income, $Y F K$ is the household's capital income, $m k p s h r_{i n s d n g}$ is the mark-up rent share, $Q_{c}$ is the composite goods supply, $n t m s h r_{i n s d n g}$ is the tariff rent share, and $I M_{m}$ is the quantity of product $m$ imported. The savings-investment balance (Equation 8 ) of the standard CGE model is modified to incorporate SINK, which denotes rents that are not redistributed. 


$$
I T+S I N K=S R O W+S G+\sum_{f} S H+\sum_{f} S_{f}
$$

where $I T$ is the total investment expenditure, $S G$ is government savings, $S R O W$ is rest-of-the-world savings, $S H$ is household savings, $S_{f}$ is savings by businesses, and $S I N K$ is the total rent.

Two accounts are added to the standard CGE models to capture total monopoly rents (Equation 9) and total rents from non-tariff measures (Equation 10).

$$
\begin{array}{ll}
\operatorname{SINKMKP}_{i}=\sum_{c}\left(1-\sum_{i \in I N S D N G} \text { mkpshr }_{c}\right)\left(P D M_{c}-P L_{c}\right) Q_{c} & \text { Eq. } 9 \\
\operatorname{SINKNTM}_{i}=\sum_{c}\left(1-\sum_{i \in I N S D N G} n t m s h r_{c}\right) n t m_{c} P W M_{i} e Q_{c} & \text { Eq. } 10
\end{array}
$$

Finally, Equation 11 defines the total as the sum of total monopoly and total income from nontariff barriers.

$$
S I N K=\operatorname{SINKMPK}_{i}+\operatorname{SINKNTM}_{i}
$$

where $\operatorname{SINKMPK}_{i}$ is the mark-up rent and $\operatorname{SINKNTM}_{i}$ is the tariff rent.

\section{Treatment of tourism}

The Egyptian social accounting matrix (SAM) used to calibrate the model includes data on tourism products (hotel and restaurant industries), the transport industry disaggregated by mode (air, land and water) and recreational, cultural and sporting services. In its standard form, the 2010/11 SAM for Egypt cannot adequately describe the expenditure patterns of inbound tourists. Therefore, as in Pham et al. (2013), it is modified slightly by separating and relabelling some elements of tourismrelated activities to incorporate inbound tourism consumption. Information on inbound tourism expenditure was obtained from Egypt's Tourism Satellite Account. ${ }^{2}$

As in Blake et al. (2008) and Njoya and Seetaram (2018), tourism demand $\left(D_{t}\right)$ is modelled similarly to export demand, and is assumed to be inversely related to the price of foreign exchange $e$ in the domestic market (Equation 12).

$$
D_{t}=\alpha \cdot \gamma \cdot\left(\frac{P T}{e}\right)^{\beta}
$$

where $\alpha$. is a parameter equal to the base level of tourism consumption. The price elasticity of demand for tourism is captured by parameter $\beta$ with $(\beta>1)$, while $\gamma$ is a shift parameter $(\gamma=1)$ in the base year. $P T$ is the average price paid by tourists.

\footnotetext{
${ }^{2}$ See https://www.oecd-ilibrary.org/sites/tour-2018-48-en/index.html?itemld=/content/component/tour-2018-48-en
} 


\section{Modelling the labour market}

Unemployment is a significant challenge facing Egypt. According to the World Bank, it stood at $11.8 \%$ per cent in 2010 (11.4\% in 2018). It is assumed that labour is unemployed with a fixed wage and is mobile among sectors, so that the market wage is determined endogenously. As in Pratt (2009), the unemployment rate $\mu$ is a function of the real wage rate:

$$
\mu=\bar{\mu} *\left(\frac{P_{\text {index }}}{w}\right)^{\alpha_{w}}
$$

where $\mu$ is base rate unemployment and $\alpha_{w}$ is the elasticity of unemployment with respect to real wages. The specification of unemployment in Equation 13 states that if the wage rate is kept above the market-clearing wage rate, the unemployment rate will increase, leading to a surplus of labour. Furthermore, the larger the elasticity of employment with respect to real wages, the higher the increase in the unemployment rate, other things being equal (Pratt, 2009).

Labour supply $L S$ is given by Equation 14:

$$
L S=(1-\mu) \overline{L S} *\left(\frac{P_{\text {index }}}{w}\right)^{\beta_{w}}
$$

where $\overline{L S}$ is the base labour supply and $\beta_{w}$ the supply response elasticity.

\section{Model closure}

A model closure refers to the choice of exogenous and endogenous variables. Moreover, model closures of static CGE models can be viewed as determining the elements of the factor market closure and the macro-economic assumptions relating to investment and government spending (Hosoe et al. 2010; Gilbert and Tower, 2013). The choice of macro closure to a large extent determines the direction of causality in a model, and affects the policy simulation results obtained with a CGE model (Lysy and Taylor, 1980; Thissen, 1998). According to Thiessen (1998), there are five types of macro-economic closure rules: Keynesian closure, Johansen closure; Neoclassical closure; Kaldorian closure and Kaleckian closure.

In this study, simulations were carried out under the assumptions of flexible government revenue, fixed current account and fixed investment. Moreover, a Keynesian closure was adopted with investment determined exogenously and savings adjusting to investments by means of changes in quantities and income. Regarding factor closure, labour is assumed to be unemployed. The consumer price index acts as the numéraire, and its value is therefore set at 1.

The trade and tourism elasticities and elasticities of substitution between labour and capital used in the model are based on Decaluwé et al. (2010), Annabi, Cockburn and Decaluwé (2006) and 
Ibrahim (2013). Annabi et al. (2006) show that trade elasticities for developing countries estimated using econometric techniques range from 0.20 (for Armington) and 0.56 (for CET) to 3.44 (for Armington) and 2.79 (for CET) for several sectors. Ibrahim (2013) points out that tourism in Egypt is very sensitive to prices, and that trade openness has a significant and positive impact on tourism demand in Egypt. We assume an elasticity of tourism demand of 1.3.

\section{Data}

The database for this study is an SAM for the Egyptian economy for the year 2010/11, developed by the Central Agency for Public Mobilization and Statistics (CAPMAS) with the support of the International Food Policy Research Institute (IFPRI). The advantage of this database is its disaggregation of the transport sector into air, water and land. The structure of the database allows for simulation of the wider economic impact of air transport reforms. It is composed of 53 activity sectors, three factors of production (labour, land and capital), and a government account, as well as enterprises, households, savings and investment, and the rest of the world (ROW).

\section{Simulation design}

Four major simulations were undertaken for this research: (1) a 10\% decrease in the mark-up on air transport services; (2) a 5\% reduction in the tariff equivalent on air transport service imports; (3) a combination of (1) and (2); and (4) a 10\% efficiency gain in the air transport sector (Table 1).

Table 1: Estimates used in air transport service reform scenarios

\begin{tabular}{l|lllll}
\hline Scenario & \multicolumn{1}{c}{} & 2 & $3(1+2)$ & \\
\hline Description & $\begin{array}{l}\text { A decrease in mark- } \\
\text { up price from } \\
\text { imperfect } \\
\text { competition }\end{array}$ & $\begin{array}{l}\text { A reduction in } \\
\text { tariff equivalent } \\
\text { protection }\end{array}$ & $\begin{array}{l}\text { A combination } \\
\text { of mark-up and } \\
\text { tariff reduction }\end{array}$ & $\begin{array}{l}\text { An } \\
\text { improvement in } \\
\text { efficiency }\end{array}$ \\
\hline Size of the shock & $10 \%$ & $5 \%$ & $15 \%$ & $10 \%$
\end{tabular}

\section{Tariff-equivalent protection}

Tariff-equivalent protection on services has previously been measured for various Egyptian sectors, including air transport (Fontagné, Guillin and Mitaritonna, 2011; Peridy and Ghoneim, 2013). Fontagné et al. (2011) compute regulation tariff equivalents focusing on cross-border trade in services. They provide tariffs equivalents for nine service sectors and 65 countries based on data from the Global Trade Analysis Project. They find that the most liberalised sector is the transport sector, with a $26 \%$ tariff protection on average. The most protected is construction, with an average tariff protection of 75\%. Tariff-equivalent protection for the Egyptian transport sector is estimated at $38.1 \%$. A study of air transport liberalisation in Egypt (OECD, 2014) indicates that tariffs on 
transport equipment (46\%) and transport and communication services (50\%) act as significant import barriers.

Peridy and Ghoneim (2013) provide an estimate of the average tariff equivalents for 15 Egyptian service sectors. Their results are in line with Fontagné et al.'s (2011) findings. They also find that transport (except sea transport), business and communications are the most liberalised sectors, with an average tariff of $21 \%$, and the most protected sector is construction (58\%). They also show a total average for ad valorem equivalent equal to 35\%, compared with $40 \%$ in Fontagné et al.'s (2011) study. Tariff-equivalent protection for Egyptian air transport is estimated at $8.9 \%$. Hoekman and Konan (2005) argue that while Egypt has taken significant steps to reduce trade barriers, nominal rates remain significantly above those in most developing countries. They simulate a $50 \%$ removal of ad valorem equivalent tariffs for transport in order to evaluate the economic impact of Egypt-US trade liberalisation. Following Peridy and Ghoneim (2013), we set the price wedge from non-tariff barriers in air transport at $9 \%$ and assume for the simulation that this price wedge decreases by $5 \%$. We do not assume a complete removal of the non-tariff barrier, but rather examine the effects of a reduction in the price wedge.

\section{Mark-ups and efficiency gaps}

There are no estimates of efficiency gaps and mark-up prices from imperfect competition in the Egyptian air transport sector. Inefficiencies in air transport show up in congestion and flight delays. Ball et al. (2010) indicate that inefficiency in the air transportation sector increases costs for airlines and businesses in other sectors, reducing associated businesses' productivity. In the absence of estimates of efficiency gaps and mark-up prices, we turn to international literature for guidance. Konan and Maskus (2006) use 15\% efficiency gains for transport to evaluate the economy-wide impact of service deregulation in Tunisia, while Davies and Van Seventer (2006) use a 10\% efficiency gain and a $30 \%$ mark-up for transport in South Africa. There is no doubt that the choice of mark-up values and efficiency gains is an essential element in the present study since they critically determine the magnitude of the response to policies-related shocks. Unlike Konan and Maskus (2006) and Davies and Van Seventer (2006), we assume lower efficiency gains and mark-ups for Egypt following the price-reducing reforms, namely $10 \%$. This can be viewed as the result of a gradual relaxation of current ownership and control restrictions in the existing air transport agreements. Thus, complete removal of restrictions is likely to produce higher efficiency gains and high reductions in mark-ups. 


\section{Results and discussion}

The simulation results are reported separately for direct, macroeconomic and industry impacts and impacts on labour and income.

\section{Direct impacts}

Table 2 presents the projected effects of reforms on the reformed sector itself with regard to price, domestic supply and demand, labour demand, trade and investment for each scenario. Reduction of the $10 \%$ mark-up on air transport services (scenario 1) would result in a $1.9 \%$ decrease in the price of air transport services, a $4.4 \%$ expansion of domestic output and a $2.2 \%$ increase in demand in the reformed sector. Demand effects are small because they arise mainly from substitution effects, as there is no significant rise in incomes to create an income effect. The reform and the resulting increase in activity levels of air transport services stimulate demand for labour, which increases by $3.3 \%$. The simulation indicates a $2 \%$ increase in exports and a $0.2 \%$ decrease in imports. Investment in the reformed sector is expected to increase by $1.9 \%$.

Table 2: Egyptian air transport industry (percentage deviation from base case)

\begin{tabular}{l|rrrr}
\hline \multicolumn{1}{c}{} & Scenario 1 & Scenario 2 & Scenario 3 & Scenario 4 \\
\hline Labour demand & 3.3 & 1.3 & 5.0 & -6.7 \\
Domestic demand & 2.2 & 2.9 & 5.3 & 0.6 \\
Export volumes & 2.0 & 1.5 & 3.6 & 6.4 \\
Price & -1.9 & -2.0 & -4.1 & -0.8 \\
Investment & 1.9 & 2.1 & 4.2 & 1.1 \\
Import volumes & -0.2 & 2.8 & 1.5 & 1.2 \\
Domestic output & 4.4 & 0.0 & 4.5 & 7.1
\end{tabular}

Source: CGE simulation results.

The direct impacts of a $5 \%$ decrease in tariff-equivalent protection on air transport service imports are given in column 3 (scenario 2) of Table 2. Removing non-tariff barriers leads to increased investment, labour and outputs of air transport services by $2.1 \%, 1.3 \%$ and $2.9 \%$, respectively. This increase in demand, initiated by a reduction in price, is satisfied by imports, which increase by $2.8 \%$, with an insignificant impact on domestic output.

The direct impacts of the simultaneous reduction of imperfect competition and non-tariff barriers are presented in column 4 of Table 2 (scenario 3). The price of air transport services falls by $4.1 \%$ relative to its baseline value. Moreover, the simultaneous elimination of market power and non-tariff barriers increases domestic supply of and demand for air transport services, as well as investments, imports and exports. As shown in Table 2, the impacts of the two reforms together are higher than the sum of their impacts when implemented separately. 
The direct impacts of improved efficiency in the air transport sector are given in column 5 of Table 2. This leads to a fall in price in the reformed sector relative to its baseline value $(0.8 \%)$, an increase in domestic output (7.1\%), a decrease in labour demand (6.7\%) and an increase in export and import volumes (6.4\% and 1.5\%). The increased domestic output and export volumes can be explained by substitution effects. Domestic demand and investment also experience a small increase.

\section{Macroeconomic impacts}

Table 3 presents the macroeconomic results of the different reforms. Implementing price-reducing reforms would result in a substantial rise in tourism export volumes and a lesser rise in GDP. Reduction of the $10 \%$ mark-up on air transport services (column 2 of Table 3) would lead to a $0.1 \%$ rise in GDP at purchasers' prices from the perspective of final demand. The impacts of GDP at factor costs and GDP at basic prices are insignificant. GDP at basic prices is the sum of value added including total government revenues from production taxes, while GDP at market prices exceeds GDP at basic prices by precisely the amount of taxes on products and imports. Furthermore, GDP at factor costs is obtained from the sum total of income, i.e. operating surplus and remuneration received by factors of production, plus taxes on products and imports. GDP at purchasers' prices is defined as the sum of household consumption, government spending, investment expenditure and tourist expenditure, plus the value of exports, minus the value of imports.

The consumer index and real exchange rate fall by $0.2 \%$ and $0.3 \%$, respectively. Moreover, the reduction of imperfect competition causes a decline in the price of air transport, which in turn alters the structure of sectoral prices and stimulates domestic demand, which rises relative to exports. Since the current account is fixed by assumption, exchange rate depreciation is required to raise exports, which increase by $1.6 \%$. Higher GDP leads to higher imports, which increase by $0.7 \%$. Government expenditure on goods and services and changes in inventories are fixed by assumption. Household income increases modestly by $0.07 \%, 0.01 \%, 0.09 \%$ and $0.1 \%$ in scenarios $1,2,3$ and 4 , respectively.

Table 3: Egyptian macroeconomic variables (percentage deviation from base case)

\begin{tabular}{l|rrrr}
\hline & Scenario 1 & Scenario 2 & Scenario 3 & Scenario 4 \\
\hline Export volumes & 1.6 & -2.8 & -1.1 & 7.7 \\
Import volumes & 0.7 & 7.1 & 8.4 & 0.6 \\
GDP at basic prices & 0.0 & 0.0 & 0.1 & 0.1 \\
GDP at purchasers' prices & 0.1 & 0.2 & 0.2 & 0.0 \\
GDP at factor costs & 0.0 & 0.1 & 0.1 & 0.1 \\
GDP at market prices & 0.0 & 0.1 & 0.2 & 0.1 \\
Gross fixed capital formation & 0.0 & 0.4 & 0.5 & 0.2 \\
Real investment & 0.0 & 0.4 & 0.3 & 0.2
\end{tabular}




\begin{tabular}{|c|c|c|c|c|}
\hline Real exchange rate & -0.1 & 0.5 & 0.3 & -0.2 \\
\hline Consumer price index & -0.2 & 0.0 & -0.2 & 0.1 \\
\hline Total household income & 0.07 & 0.01 & 0.09 & \\
\hline Total government income & -0.1 & 0.2 & 0.0 & \\
\hline Household savings & 0.0 & 0.1 & 0.0 & \\
\hline Government savings & -0.3 & -1.5 & -1.9 & \\
\hline Tourism export volumes & 0.3 & 0.0 & 0.3 & \\
\hline Unemployment rate & -0.04 & -0.01 & -0.06 & \\
\hline Rent (million EGP) & 172.5 & 95.2 & 124.1 & \\
\hline
\end{tabular}

Source: CGE simulation results.

In column 3 of Table 3 , it can be seen that a $5 \%$ reduction in the tariff equivalent on air transport services is expected to increase GDP at purchasers' prices by $0.2 \%$, GDP at factor costs and market prices by $0.1 \%$ and imports by $7.1 \%$. Thus, the reduction in tariff-equivalent protection causes a decrease in the price of imports, leading to a shift toward imported intermediate inputs of air transport and away from domestic production. Thus, while demand is stimulated, the increase is satisfied largely by imported rather than domestic air transport. Total exports decrease by $2.8 \%$ owing to an appreciation in exchange rates, which increases by $0.5 \%$ despite the decrease in import and domestic prices. Unlike the first scenario, in which exports grow faster than imports, the trade balance deteriorates. Real investment and capital stock rise by $0.4 \%$. As illustrated in column 4 of Table 3, the fall in exports resulting from the reduction of tariff-equivalent barriers $(-2.8 \%)$ is offset by the cost-reducing effects of reduced mark-up (-1.1) when both measures are implemented simultaneously. Removing mark-ups raises GDP by $0.1 \%$, while total export volumes increase by $7.7 \%$ and import volumes by $0.6 \%$. This in line with findings by Konan and Maskus (2006), Jensen, Rutherford and Tarr (2006) and Balistreri et al. (2008), which indicate that the GDP implications of service reforms are positive.

There is no significant rise in household incomes and savings owing to the assumption of flexible wages. In other words, the expansion of labour does not necessarily raise incomes, as would be the case if wages were fixed. The simulations indicate that household capital income grows faster than labour income. With the exception of efficiency reforms, government savings decline with monopoly and non-tariff barrier reforms. The government deficit can be explained by a loss of import duties and monopoly rents and an increase in government transfers to households. With the exception of the reduction of non-tariff barriers, implementing price-reducing reforms would result in a significant rise in tourism export volumes. This result is consistent with previous studies that find a positive relationship between air transport policies and tourism growth (Omar and Sekkat, 2012; Micco and Serebrisky, 2004; Seetaram et al., 2014; Forsyth et al., 2015). As illustrated in Table 
3, the economic growth induced by the various reforms calls for greater use of labour, resulting in a modest decrease in unemployment under all scenarios, with the highest impact recorded under scenario $1(-0.04 \%)$. The aggregate impact of scenarios 1 and 2 is slightly more than additive at $-0.06 \%$. The values of the monopoly rents and incomes from non-tariff barriers under simulations 1, 2 and 3 are 172.5 million EGP, 95.2 million EGP and 124.1 million EGP, respectively.

\section{Industry impacts}

The impacts of price-reducing reforms on other sectors are presented in Table 4. Reductions in the prices of reformed services feed through as reduced input costs for other sectors.

Table 4: Egyptian industry output (percentage deviation from base case)

\begin{tabular}{l|cccc}
\hline & Scenario 1 & Scenario 2 & Scenario 3 & Scenario 4 \\
\hline $\begin{array}{l}\text { Mining, quarrying and mining support } \\
\text { service activities }\end{array}$ & 1.7 & 0.6 & 2.6 & 0.4 \\
Manufacture of other transport & & & & \\
equipment & 2.0 & 0.5 & 2.5 & 0.3 \\
Arts, entertainment and recreation & 0.5 & 0.2 & 0.8 & 0.0 \\
Warehousing and support activities for & & & & \\
transportation & 0.2 & 0.2 & 0.8 & 0.2 \\
Agriculture & 0.0 & 0.0 & 0.0 & 0.0 \\
All other services & 0.0 & 0.0 & 0.0 & 0.0 \\
Manufacture of computer, electronic & & & & 0.0 \\
and optical products & 0.1 & 0.0 & 0.2 & 0.1 \\
Land transport and transport via & & & & 0.1 \\
pipelines & 0.1 & 0.0 & 0.2 & 0.1 \\
Other personal service activities & 0.3 & 0.0 & 0.4 & 0.0 \\
Public administration and defence; & & & & 0.3 \\
compulsory social security & 0.3 & 0.0 & 0.2 & 0.0 \\
Information and communication & 0.1 & 0.0 & 0.2 & 0.1 \\
Water transport & 0.2 & 0.0 & 0.2 & 0.0 \\
Accommodation & 0.0 & 0.0 & 0.2 & 0.1
\end{tabular}

Source: CGE simulation results.

As can be seen in Table A1 in the Appendix, the reforms result in a decrease in the intermediate consumption price of industries that use air transport relatively intensively, while sectors that use relatively few inputs from air transport experience an increase or no change. Columns 1 and 2 of Table A1 show the shares of value added and intermediates in the gross outputs of each sector, while column 3 shows the shares of air transport. The sectors are arranged in descending order of shares of air transport; hence, other mining and quarrying are the most intensive in their use of air transport as inputs, accounting for $3.4 \%$ of gross output.

Thus, the initial reduction in the costs of sectors using air transport stimulates production and increases demand for inputs, which in turn creates pressures for price-increases. This explains the 
rise in the input prices of sectors that use relatively few inputs from air transport. This is in line with Davies and Van Seventer's (2006) finding that, with few exceptions, sectors that use relatively little transport and telecommunications (reformed sectors in their study) experience a net rise in input prices, as the price-increasing effects of higher demand more than outweigh the price-reducing effects of the reformed sector.

All three reforms raise the outputs of mining, quarrying and mining support service activities, manufacturing of other transport equipment, warehousing and support activities for transportation, and tourism-related services, including accommodation, food and beverage service activities and transport. Moreover, the three reforms have no effects on agriculture and other sectors that are not complementary to air transport, indicating a weak link between the agricultural and air transport industries. The reduction of monopoly power provides a relatively significant stimulus to mining, quarrying and mining support service activities and manufacturing of other transport equipment. Moreover, the degree to which the changes to air transport affect individual sectors depends mainly on the demand shares of the sector. Thus, a large proportion of the air transport sector's expenditure is on mining, quarrying and mining support service activities and manufacturing of other transport equipment, explaining the magnitude of the impact on these sectors.

\section{Impacts on labour demand}

Table 5 presents the impacts of the reforms on demand for labour at a sectoral level. These map onto the impacts mentioned above for outputs at a sectoral level. Mining, quarrying and mining support service activities and manufacturing of other transport equipment are amongst the sectors with the highest employment expansion. Since wages are flexible and labour supplies elastic by assumption, the increased demand for labour is met, in effect, by drawing unemployed people into production.

Table 5: Egyptian industry labour demand (percentage deviation from base case)

\begin{tabular}{l|rrrr} 
& Scenario 1 & Scenario 2 & Scenario 3 & Scenario 4 \\
\hline Mining, quarrying and mining support service & & & & \\
activities & 2.0 & 0.7 & 2.8 & 0.7 \\
Manufacture of other transport equipment & 1.2 & 0.4 & 1.7 & 0.2 \\
Other personal service activities & 0.5 & 0.1 & 0.7 & 0.1 \\
Warehousing and support activities for & & & & \\
transportation & 0.8 & 0.1 & 1.0 & 0.2 \\
Agriculture & 0.0 & 0.0 & 0.0 & 0.0 \\
All other services & 0.0 & 0.0 & 0.0 & 0.0 \\
Arts, entertainment and recreation & 1.0 & 0.0 & 0.9 & 0.4 \\
Manufacture of computer, electronic and & & & & 0.1 \\
optical products & & 0.1 & 0.0 & 0.0
\end{tabular}


Land transport and transport via pipelines

Public administration and defence;

compulsory social security

Information and communication

Water transport

Accommodation

Food and beverage service activities

Source: CGE simulation results

$\begin{array}{llll}0.1 & 0.0 & 0.1 & 0.0 \\ & & & \\ 0.6 & 0.0 & 0.6 & 0.2 \\ 0.6 & 0.0 & 0.5 & 0.2 \\ 0.8 & 0.0 & 0.8 & 0.2 \\ 0.0 & 0.0 & 0.1 & 0.0 \\ 0.0 & 0.0 & 0.1 & 0.0\end{array}$

\section{Conclusions}

This paper has examined the impacts on tourism and the wider economy of price-reducing reforms to air transport services in Egypt. Since 2002, the Egyptian air transport sector has undergone various reforms, including infrastructure improvement, liberalisation and modification of the requirement to establish private airline companies, which have relaxed entry and affected the sector's performance. However, despite the positive steps toward restructuring, the sector is economically concentrated at both domestic and regional levels, with air services dominated by the national flag carrier and no real competition from other carriers. Lowering regulatory and practical barriers that prevent other airlines from operating in the market would enhance participation, increase competition and reduce prices. A general insight from the literature is that further reforms would lead to an increase in efficiency and a decrease in prices. Furthermore, little previous research has evaluated the wider economic impact of air transport policy in Egypt. In using a CGE approach that departs from perfect competition and explicitly models the air transport sector, this paper examines the economy-wide impacts of aviation price-reducing reforms, covering a range of different scenarios.

The findings reveal that reforms focused on reducing the prices of air transport services and enhancing productivity are positively associated with higher GDP growth. Moreover, price-reducing reforms increase tourism exports, GDP and other macroeconomic variables, labour demand and the outputs of a number of sectors. Although the direct impacts of the reforms are negative for some agents, there is an overall positive effect, indicating that the benefits derived from price-reducing reforms outweigh the costs incurred by the reforming sector. Moreover, improved productivity is expected to decrease labour demand for air transport services, while removing mark-up and trade barriers would lead to a reduction in rents accruing to air transport producers. Thus, the gains arising from indirect economy-wide effects on production are passed to other sectors by multiplier effects. Sectors that are complementary to air transport are the primary beneficiaries of the reforms. Given 
their anticipated positive impact on tourism and the wider economy, Egypt would benefit from pursuing reforms to the air transport industry.

The primary limitation of this research is data availability. The parameters, elasticities, markups and efficiency values used in this study are drawn from external sources. Therefore, the study might be improved by estimating the mark-up and elasticity parameters econometrically where appropriate data are available. Future research might also explore the long-term impacts of the reforms, for example in generating employment in the reformed sector and the economy as a whole, using a dynamic CGE model. Of interest to policy makers is also the distributional impact of the reforms in terms of which segments of the population experience gains and losses. 


\section{Appendix}

Table A1: Structure of inputs

\begin{tabular}{|c|c|c|c|c|}
\hline & \multicolumn{3}{|c|}{ Share in gross output (\%) } & \multirow[t]{2}{*}{$\begin{array}{l}\text { \% change in } \\
\text { price of } \\
\text { intermediate } \\
\text { aggregate of } \\
\text { all three } \\
\text { measures } \\
\end{array}$} \\
\hline & Value added & Intermediates & Air transport & \\
\hline Other mining and quarrying & 76.7 & 23.3 & 3.4 & -6.1 \\
\hline $\begin{array}{l}\text { Manufacture of other transport } \\
\text { equipment }\end{array}$ & 48.0 & 52.0 & 2.6 & -5.5 \\
\hline Air transport & 49.8 & 50.2 & 2.4 & -1.1 \\
\hline $\begin{array}{l}\text { Public administration and defence; } \\
\text { compulsory social security }\end{array}$ & 69.5 & 30.5 & 2.3 & -0.1 \\
\hline Other personal service activities & 72.3 & 27.7 & 2.0 & -0.4 \\
\hline $\begin{array}{l}\text { Manufacture of computer, } \\
\text { electronic and optical products }\end{array}$ & 32.9 & 67.1 & 1.9 & -5.9 \\
\hline Information and communication & 66.1 & 33.9 & 1.7 & -0.7 \\
\hline Arts, entertainment and recreation & 83.2 & 16.8 & 1.6 & -0.6 \\
\hline Mining support service activities & 96.7 & 3.3 & 1.2 & -0.3 \\
\hline $\begin{array}{l}\text { Warehousing and support activities } \\
\text { for transportation }\end{array}$ & 88.8 & 11.2 & 1.1 & -0.7 \\
\hline $\begin{array}{l}\text { Manufacture of machinery and } \\
\text { equipment N.E.C. }\end{array}$ & 26.2 & 73.8 & 1.0 & 0.4 \\
\hline $\begin{array}{l}\text { Total of wholesale and retail trade; } \\
\text { repair of motor vehicles and } \\
\text { motorcycles }\end{array}$ & 70.9 & 29.1 & 0.9 & 0.4 \\
\hline Manufacture of tobacco products & 48.2 & 51.8 & 0.9 & 0.0 \\
\hline $\begin{array}{l}\text { Activities of membership } \\
\text { organisations }\end{array}$ & 40.9 & 59.1 & 0.7 & 0.3 \\
\hline $\begin{array}{l}\text { Manufacture of wood and products } \\
\text { of wood and cork, except furniture; } \\
\text { manufacture of articles from straw } \\
\text { and plaiting materials }\end{array}$ & 80.3 & 19.7 & 0.7 & 0.1 \\
\hline $\begin{array}{l}\text { Manufacture of motor vehicles, } \\
\text { trailers and semi-trailers }\end{array}$ & 30.0 & 70.0 & 0.7 & 0.2 \\
\hline Education & 84.9 & 15.1 & 0.7 & 0.1 \\
\hline $\begin{array}{l}\text { Printing and reproduction of } \\
\text { recorded media }\end{array}$ & 73.9 & 26.1 & 0.6 & 0.1 \\
\hline $\begin{array}{l}\text { Manufacture of basic } \\
\text { pharmaceutical products and } \\
\text { pharmaceutical preparations }\end{array}$ & 48.6 & 51.4 & 0.6 & 0.1 \\
\hline Manufacture of furniture & 34.6 & 65.4 & 0.6 & 0.1 \\
\hline $\begin{array}{l}\text { Manufacture of electrical } \\
\text { equipment }\end{array}$ & 26.5 & 73.5 & 0.6 & 0.0 \\
\hline Manufacture of wearing apparel & 41.2 & 58.8 & 0.5 & 0.0 \\
\hline $\begin{array}{l}\text { Professional, scientific and } \\
\text { technical activities }\end{array}$ & 90.1 & 9.9 & 0.5 & 0.1 \\
\hline $\begin{array}{l}\text { Extraction of crude petroleum and } \\
\text { natural gas }\end{array}$ & 95.9 & 4.1 & 0.4 & 0.1 \\
\hline $\begin{array}{l}\text { Administrative and support service } \\
\text { activities }\end{array}$ & 85.1 & 14.9 & 0.4 & 0.0 \\
\hline $\begin{array}{l}\text { Repair and installation of } \\
\text { machinery and equipment }\end{array}$ & 95.0 & 5.0 & 0.4 & 0.0 \\
\hline
\end{tabular}




\begin{tabular}{|c|c|c|c|c|}
\hline Total of construction & 48.2 & 51.8 & 0.4 & 0.1 \\
\hline $\begin{array}{l}\text { Manufacture of rubber and plastics } \\
\text { products }\end{array}$ & 27.5 & 72.5 & 0.4 & 0.0 \\
\hline $\begin{array}{l}\text { Manufacture of fabricated metal } \\
\text { products, except machinery and } \\
\text { equipment }\end{array}$ & 28.8 & 71.2 & 0.4 & 0.0 \\
\hline Manufacture of textiles & 35.8 & 64.2 & 0.3 & 0.0 \\
\hline $\begin{array}{l}\text { Manufacture of other non-metallic } \\
\text { mineral products }\end{array}$ & 54.1 & 45.9 & 0.3 & 0.0 \\
\hline Postal and courier activities & 84.1 & 15.9 & 0.3 & 0.0 \\
\hline Manufacture of beverages & 39.3 & 60.7 & 0.3 & 0.0 \\
\hline $\begin{array}{l}\text { Manufacture of chemicals and } \\
\text { chemical products }\end{array}$ & 62.2 & 37.8 & 0.3 & 0.0 \\
\hline $\begin{array}{l}\text { Manufacture of leather and related } \\
\text { products }\end{array}$ & 56.2 & 43.8 & 0.3 & 0.0 \\
\hline $\begin{array}{l}\text { Repair of computers and personal } \\
\text { and household goods }\end{array}$ & 59.4 & 40.6 & 0.3 & 0.0 \\
\hline Mining of metal ores & 95.2 & 4.8 & 0.2 & 0.0 \\
\hline $\begin{array}{l}\text { Manufacture of paper and paper } \\
\text { products }\end{array}$ & 79.4 & 20.6 & 0.2 & 0.0 \\
\hline $\begin{array}{l}\text { Land transport and transport via } \\
\text { pipelines }\end{array}$ & 72.0 & 28.0 & 0.1 & 0.0 \\
\hline $\begin{array}{l}\text { Human health and social work } \\
\text { activities }\end{array}$ & 56.2 & 43.8 & 0.1 & 0.0 \\
\hline Water transport & 93.2 & 6.8 & 0.1 & 0.0 \\
\hline Financial and insurance activities & 90.8 & 9.2 & 0.1 & 0.0 \\
\hline Other manufacturing & 10.4 & 89.6 & 0.1 & 0.0 \\
\hline Manufacture of basic metals & 26.4 & 73.6 & 0.1 & 0.0 \\
\hline $\begin{array}{l}\text { Food and beverage service } \\
\text { activities }\end{array}$ & 48.9 & 51.1 & 0.0 & 0.0 \\
\hline Accommodation & 55.7 & 44.3 & 0.0 & 0.0 \\
\hline $\begin{array}{l}\text { Manufacture of coke and refined } \\
\text { petroleum products }\end{array}$ & 14.1 & 85.9 & 0.0 & 0.0 \\
\hline Water and sewerage & 72.0 & 28.0 & 0.0 & 0.0 \\
\hline $\begin{array}{l}\text { Electricity, gas, steam and air } \\
\text { conditioning supply }\end{array}$ & 15.4 & 84.6 & 0.0 & 0.0 \\
\hline Real estate activities & 94.9 & 5.1 & 0.0 & 0.0 \\
\hline $\begin{array}{l}\text { Crop and animal production, } \\
\text { hunting and related service } \\
\text { activities }\end{array}$ & 70.3 & 29.7 & 0.0 & 0.0 \\
\hline Fishing and aquaculture & 91.1 & 8.9 & 0.0 & 0.0 \\
\hline Manufacture of food products & 28.4 & 71.6 & 0.0 & 0.0 \\
\hline
\end{tabular}




\section{References}

Abayasiri-Silva, K., \& Horridge, M. (1998). The effects of current fiscal restraint on the Australian economy: An applied general equilibrium analysis with imperfect competition. Working Paper op-91, Centre of Policy Studies/IMPACT Centre, Victoria University, Melbourne, Australia.

Abeyratne, R. I. (1993). Air transport tax and its consequences on tourisms. Annals of Tourism Research, 20(3), 450-460.

Andriamananjara, S., Ferrantino, M., \& Tsigas, M. (2005). Alternative approaches in estimating the economic effects of non-tariff measures: Results from newly quantified measures. In P. Dee \& M. Ferrantino (eds), Quantitative Methods for Assessing the Effects of Non-Tariff Measures and Trade Facilitation (pp. 525-540). Singapore: World Scientific.

Annabi, N., Cockburn, J., \& Decaluwé, B. (2006). Functional forms and parametrization of CGE models. PEP Working Paper No. 2006-04, Partnership for Economic Policy, Université Laval, Quebec, Canada.

Armington, P. S. (1969). A theory of demand for products distinguished by place of production. IMF Staff Paper, 16(1), 159-178.

Aziz, H. (1995). Understanding attacks on tourists in Egypt. Tourism Management, 16(2), 91-95.

Balistreri, E., Rutherford, T., \& Tarr, D. (2008). Modeling services liberalization: The case of Kenya. Policy Research Working Paper 4544, The World Bank, Washington, DC.

Ball, M., Barnhart, C., Dresner, M., Hansen, M., Neels, K., Odoni, A., Peterson, E., Sherry, L., Trani, A., \& Zou, B. (2010). Total delay impact study. Paper presented at NEXTOR Research Symposium, Washington, DC.

Baloglu, S., \& Mangaloglu, M. (2001). Tourism destination images of Turkey, Egypt, Greece, and Italy as perceived by US-based tour operators and travel agents. Tourism Management, 22(1), 1-9.

Bieger, T., \& Wittmer, A. (2006). Air transport and tourism: Perspectives and challenges for destinations, airlines and governments. Journal of Air Transport Management, 12(1), 40-46.

Blake, A.T., Arbache, J.S., Sinclair, M.T. \& Teles, V. (2008). Tourism and poverty relief. Annals of Tourism Research. 35(1), pp.107-126.

Cockburn, J., Robichaud, V., \& Tiberti, L. (2018). Energy Subsidy Reform and Poverty in Arab Countries: A Comparative CGE-Microsimulation Analysis of Egypt and Jordan. Review of Income and Wealth, 64, S249-S273.

Cristea, A., Hillberry, R., \& Mattoo, A. (2015). Open Skies over the Middle East. Washington, DC: The World Bank.

Crouch, G. I. (1992). Effect of income and price on international tourism. Annals of Tourism Research, 19(4), 643-664.

Davies, R., \& Van Seventer, D. E. N. (2006). The Economy-Wide Effects of Price-Reducing Reforms in Infrastructure Industries in South Africa. Cape Town, South Africa: Human Sciences Research Council.

Debbage, K. G. (2002). Airport runway slots: Limits to growth. Annals of Tourism Research, 29(4), 933-951.

Decaluwé, B., Lemelin, A., Robichaud, V., \& Maisonnave, H. (2010). The PEP standard computable general equilibrium model single-country, recursive dynamic version PEP-1-1. Poverty and Economic Policy Research Network [website]. Available at https://www.pep-net.org/pep-1-1single-country-static-version. 
Dixit, A. K., \& Stiglitz, J. E. (1977). Monopolistic competition and optimum product diversity. The American Economic Review, 67(3), 297-308.

Duval, D. T. (2013). Critical issues in air transport and tourism. Tourism Geographies, 15(3), 494-510.

Dwyer, L., \& Forsyth, P., eds (2007). International Handbook on the Economics of Tourism. Cheltenham: Edward Elgar Publishing.

Dwyer, L., Forsyth, P., \& Spurr, R. (2004). Evaluating tourism's economic effects: New and old approaches. Tourism Management, 25(3), 307-317.

Elbehri, A., \& Hertel, T. (2004). A comparative analysis of the EU-Morocco FTA vs. multilateral liberalization. GTAP Working Paper 1643, Center for Global Trade Analysis, Department of Agricultural Economics, Purdue University, West Lafayette, IN.

Elshahawany, D. N., Haddad, E. A., \& Lahr, M. L. (2017). Accessibility, transportation cost, and regional growth: A case study for Egypt. Middle East Development Journal, 9(2), 256-277.

Eraqi, M. I. (2006). Tourism services quality (TourServQual) in Egypt: The viewpoints of external and internal customers. Benchmarking: An International Journal, 13(4), 469-492.

Eraqi, M. I. (2007). Local communities' attitudes towards impacts of tourism development in Egypt. Tourism Analysis, 12(3), 191-200.

Evans, D., Gasiorek, M., Robinson, S., \& McDonald, S. (2006). Trade liberalisation with trade induced technical change in Morocco and Egypt. Topics in Middle Eastern and North African Economies, electronic journal, 8.

Export.gov (n.d.). https://www.export.gov/article?id=Egypt-Market-Overview.

Fielding, D., \& Shortland, A. (2011). How do tourists react to political violence? An empirical analysis of tourism in Egypt. Defence and Peace Economics, 22(2), 217-243.

Fontagné, L., Guillin, A., \& Mitaritonna, C. (2011). Estimations of tariff equivalents for the services sectors. Working paper, Centre d'Études Prospectives et d'Informations Internationales, Paris, France.

Forsyth, P. (2006). Martin Kunz memorial lecture: Tourism benefits and aviation policy. Journal of Air Transport Management, 12(1), 3-13.

Forsyth, P., Niemeier, H.-M., \& Njoya, E. (2015). Economic evaluation of investments in airports: A survey of old and new approaches. Mimeo, Monash University, Australia.

Gilbert, J., \& Tower, E. (2012). Introduction to numerical simulation for trade theory and policy. World Scientific Publishing Company.

Graham, A., Papatheodorou, A., \& Forsyth, P., eds (2008). Aviation and Tourism: Implications for Leisure Travel. Farnham: Ashgate.

Gray, M. (1998). Economic reform, privatization and tourism in Egypt. Middle Eastern Studies, 34(2), 91-112.

Harris, R. (1984). Applied general equilibrium analysis of small open economies with scale economies and imperfect competition. Am. Econ. Rev. 74 (5), 1016-1032.

Hendy, R., \& Zaki, C. (2010). Rethinking the redistribution effects of trade liberalization in Egypt: A microsimulation analysis. MPRA Paper 23354, University Library of Munich, Germany.

Hoekman, B., \& Konan, D. E. (2005). Deepening Egypt-US trade integration: Economic implications of alternative options. Working Paper 200501, Department of Economics, University of Hawaii at Manoa, Hawaii, $\mathrm{HI}$.

Hosoe, N., Gasawa, K., \& Hashimoto, H. (2010). Textbook of Computable General Equilibrium Modeling: Programming and Simulations. London: Palgrave Macmillan. 
IATA (2014). Transforming Intra-African Air Connectivity: The Economic Benefits of Implementing the Yamoussoukro Decision. Montreal, Canada: IATA.

IATA (2017). The Importance of Air Transport to Egypt. Oxford: Oxford Economics. Available at https://www.iata.org/policy/Documents/benefits-of-aviation-egypt-2017.pdf.

IATA (2018). The importance of air transport to Egypt. Available at https://www.iata.org/policy/Documents/benefits-of-aviation-egypt-2017.pdf

Ibrahim, M. A. M. A. (2013). The determinants of international tourism demand for Egypt: Panel data evidence. European Journal of Economics, Finance and Administrative Sciences, 30, 50-58.

ICAO (2013). Egyptian experience in the liberalization of air carrier ownership. Paper presented at the Sixth Meeting of the Worldwide Air Transport Conference, Montreal, Canada, 18-22 March. Available at https://www.icao.int/Meetings/atconf6/Documents/WorkingPapers/ATConf6wp041_en.pdf.

ICAO (2016). Overview of regulatory and industry developments In international air transport. Montreal, Canada: ICAO Secretariat. Available at https://www.icao.int/Meetings/a39/Documents/Overview_of_Regulatory_and_Industry_Dev elopments_in_International_Air_Transport.pdf.

Ikiara, M. M., \& Nyangito, H. (2001). Effects of visa waiver and increase in airport tax on Kenya's tourism industry. Policy Paper No. 3, Kenya Institute for Public Policy Research and Analysis, Nairobi, Kenya.

Jensen, J., Rutherford, T., \& Tarr, D. (2008). Modeling services liberalization: The case of Tanzania. Policy Research Working Paper 4801, World Bank, Washington, DC.

Kincaid, I., \& Tretheway, M. (2016). Economic impact of aviation liberalization. In H. Wolf, P. Forsyth, D. Gillen, K. Hüschelrath, \& H.-M. Niemeier (eds), Liberalization in Aviation (pp. 367-392). London: Routledge.

Konan, D. E., \& Kim, K. E. (2004). Beyond border barriers: The liberalisation of services trade in Tunisia and Egypt. World Economy, 27(9), 1429-1447.

Konan, D. E., \& Maskus, K. E. (2006). Quantifying the impact of services liberalization in a developing country. Journal of Development Economics, 81(1), 142-162.

Konan, D. E., \& Van Assche, A. (2007). Regulation, market structure and service trade liberalization. Economic Modelling, 24(6), 895-923.

Lofgren, H. (1994). Egypt's experience from CGE modeling: A critical review. Working paper 9411, Economic Research Forum, Cairo, Egypt.

Lysy, F., \& Taylor, L. (1980). The general equilibrium income distribution model. In L. Taylor, E. Bacha, E. Cardoso, \& F. Lysy (eds), Models of Growth and Distribution for Brazil (pp. 128-139). Oxford: Oxford University Press.

Maskus, K. E., \& Konan, D. E. (1997). Trade liberalization in Egypt. Review of Development Economics, $1(3), 275-293$.

Mayor, K., \& Tol, R. S. (2010). The impact of European climate change regulations on international tourist markets. Transportation Research Part D: Transport and Environment, 15(1), 26-36.

Micco, A., \& Serebrisky, T. (2004). Infrastructure, Competition Regimes, and Air Transport Costs: Cross-Country Evidence. Washington, DC: The World Bank.

Njoya, E. T., Christidis, P., \& Nikitas, A. (2018). Understanding the impact of liberalisation in the EUAfrica aviation market. Journal of Transport Geography, 71, 161-171.

Njoya, E. T., \& Seetaram, N. (2018). Tourism contribution to poverty alleviation in Kenya: A dynamic computable general equilibrium analysis. Journal of Travel Research, 57(4), 513-524. 
Nugent, J. B. (1988). Foreign aid, economic development and income distribution: Some inferences from a CGE model for Egypt. In J. K. Sengupta \& G. K. Kadekodi (eds), Econometrics of Planning and Efficiency (pp. 63-90). New York, NY: Springer.

O'Connell, J. F., \& Warnock-Smith, D. (2012). Liberalization and strategic change in air transport: An examination of current and future variations in tourist traffic to and from Egypt resulting from policy changes at EgyptAir. Tourism Economics, 18(4), 845-870.

OECD (2014). Airline competition. Paper DAF/COMP/WD(2014)32, Directorate for Financial and Enterprise Affairs Competition Committee, OECD, Paris, France. Available at http://www.oecd.org/officialdocuments/publicdisplaydocumentpdf/?cote=DAF/COMP/WD(2 014)32\&docLanguage $=$ En.

Omar, N. S., \& Sekkat, K. (2012). Egypt airline passengers market: Competition and performance. Working Paper No. 669, Economic Research Forum, Giza, Egypt.

Oxford Economic Forecasting (2003). The contribution of air transport to sustainable development in Africa. Unpublished Final Report for the Air Transport Action Group. Available at www. atag. org.

Péridy, N., \& Ghoneim, A. (2013). Middle East and North African integration: Through the lens of non-tariff measures. Journal of Economic Integration, 28(4), 580-609.

Pham, T.D., Bailey, G., \& Spurr, R. (2013). The positive and negative effects of the mining boom: A technical paper. Tourism Research Australia, Canberra, Australia.

Pizam, A., \& Smith, G. (2000). Tourism and terrorism: A quantitative analysis of major terrorist acts and their impact on tourism destinations. Tourism Economics, 6(2), 123-138.

Pratt, S. A. (2009). The economic impact of uncertain tourism demand in Hawaii: Risk in a computable general equilibrium model. PhD thesis, University of Nottingham, Nottingham.

Richter, T., \& Steiner, C. (2008). Politics, economics and tourism development in Egypt: Insights into the sectoral transformations of a neo-patrimonial rentier state. Third World Quarterly, 29(5), 939-959.

Robinson, S., \& Gehlhar, C. G. (1995). Land, water, and agriculture in Egypt: The economywide impact of policy reform. TMD Discussion Paper 1, International Food Policy Research Institute, Washington, DC.

Roson, R. (2006). Introducing imperfect competition in CGE models: Technical aspects and implications. FEEM Working Paper No. 3.2006, Fondazione Eni Enrico Mattei, Milan, Italy.

Sakr, M., Massoud, N., \& Sakr, H. (2009). Tourism in Egypt: An unfinished business. Working Paper No. 147, Egyptian Center for Economic Studies, Cairo, Egypt.

Schlumberger, C. E., \& Weisskopf, N. (2012). Is the Arab take-off imminent? Opportunities for the development of the North African air transport sector following the Arab Spring. Annals of Air and Space Law, 37, 245-275.

Seetaram, N., Song, H., \& Page, S. J. (2014). Air passenger duty and outbound tourism demand from the United Kingdom. Journal of Travel Research, 53(4), 476-487.

Thissen, M. J. P. M. (1998). Two decades of CGE modelling lessons from models for Egypt. Research Report 99C02, Research Institute SOM, University of Groningen, Netherlands.

Tohamy, S. (1999). Case Study of Egypt's Service Liberalization, Service Barriers and Implementation of the GATS Agreement. Cairo, Egypt: Economic Research Forum for the Arab Countries, Iran and Turkey.

Tol, R. S. (2007). The impact of a carbon tax on international tourism. Transportation Research Part D: Transport and Environment, 12(2), 129-142. 
UNWTO (2017). Tourism Highlights. Madrid, Spain: UN World Tourism Organization. Available at https://www.e-unwto.org/doi/pdf/10.18111/9789284419029.

Vandervoort, C., \& Morgan, M. (1999). Reducing transport costs of Egypt's exports. DEPRA Project, Nathan Associates Inc.

Vignal, L. (2010). The new territories of tourism in Egypt: A local-global frontier? Cybergeo: European Journal of Geography, doc. 509, doi:10.4000/cybergeo.23324.

Wahab, S. E. (1996). Tourism development in Egypt: Competitive strategies and implications. Progress in Tourism and Hospitality Research, 2(3-4), 351-364.

WTTC (2005). Aviation in Egypt: The Impact on Travel \& Tourism, Jobs and the Economy. London: World Travel \& Tourism Council. Available at http://www.ontit.it/opencms/export/sites/default/ont/it/documenti/archivio/files/ONT_200 5-10-07_00158.pdf.

WTTC (2018). Travel \& Tourism Economic Impact. London: World Travel \& Tourism Council. Available at https://www.wttc.org/-/media/files/reports/economic-impactresearch/countries-2018/egypt2018.pdf.

Zaki, C. (2009). Rethinking the effect of cutting red tape in Egypt: A dynamic CGE analysis. Working paper, Centre d'Economie de la Sorbonne, Paris.

Zaki, C. (2010). Towards an explicit modeling of trade facilitation in CGE models: Evidence from Egypt. Working Paper 515, Economic Research Forum, Giza, Egypt.

Zaki, C. (2013). Trade facilitation and corruption: A CGE model of Egypt. The Journal of North African Studies, 18(1), 70-111. 